\title{
Organizational Justice Perception of Work Performance and Relationship of Work Performance with the Organizational Opposition Level: A Study on Physical Education and Sports Teachers (Istanbul Province Example
}

\section{Percepción de justicia organizacional Del desempeño laboral y relación Del desempeño laboral con el nivel de oposición organizacional: Un estudio sobre profesores de educación física y deportes (ejemplo de la provincia de Estambul}

\section{Aydın Pekel}

İstanbul Gelişim Üniversitesi University, School of Physical Education and Sport, İstanbul, TURKEY

ORCID ID: https://orcid.org/0000-0003-0238-1081

*Correspondence

Email: apekel@gelisim.edu.tr
Cite as:

Pekel, A. (2021). Organizational Justice Perception of Work Performance and Relationship of Work Performance with the Organizational Opposition Level: A Study on Physical Education and Sports Teachers (Istanbul Province Example. Propósitos y Representaciones, 9 (SPE3), e1205. Doi: http://dx.doi.org.10.20511.pyr2021.v9nSPE3.1205 
Organizational Justice Perception of Work Performance and Relationship of Work Performance with the Organizational Opposition Level: A Study on Physical Education and Sports Teachers (Istanbul Province Example

\section{Summary}

The aim of this study is to examine the relationship between the job performance of physical education and sports teachers and their level of organizational justice and opposition. The study group was composed of 575 physical education and teachers of sports who were selected by the simple random method among individuals who worked as physical education and sports teachers in the state schools affiliated to the Istanbul Provincial Directorate of National Education in the 2019-2020 academic year. Data collection methods and tools used in this research; personal information sheet, job performance, organizational justice and organizational opposition scales were implemented. The obtained data were recorded with IBM SPSS 22.0 (version) package program and the all analyzes were accomplished with this statistics program. Descriptive information, subtitles and total scores of the scales were given by determining the frequency (f) and percentage (\%) values. Correlation analysis was used as a statistical procedure. As a result, while there was no correlation between physical education and teachers of sport job performance and procedural justice, one of the subtitles of perception of justice, a low level of negative correlation was found between interaction, distributive justice and attitude towards organizational justice total score. Again, no relationship was found between job performance and the total score of vertical and horizontal opposition and organizational opposition which are sub-headings of organizational opposition. This may be due to the fact that administrators do not adequately reward the job performances of physical education and sports teachers due to increasing interest of managers towards teachers who conduct lessons for exams important in terms of students. In addition, it is thought to be caused that physical education and sports teachers do not have any difficulties in expressing themselves due to both their professional competencies and their selfexpression and high communication skills that physical education and sports bring them.

Keywords: Physical education and sports, teacher, job performance, organizational justice, perception, organizational opposition.

\section{Resumen}

El objetivo de este estudio es examinar la relación entre el desempeño laboral de los profesores de educación física y deportes y su nivel de justicia organizacional y oposición. El grupo de estudio estuvo compuesto por 575 profesores de educación física y deportes que fueron seleccionados por el método aleatorio simple entre individuos que trabajaron como profesores de educación física y deportes en las escuelas estatales afiliadas a la Dirección Provincial de Educación Nacional de Estambul en el curso académico 2019-2020. año. Métodos y herramientas de recopilación de datos utilizados en esta investigación; Se implementaron escalas de hoja de información personal, desempeño laboral, justicia organizacional y oposición organizacional. Los datos obtenidos se registraron con el programa de paquete IBM SPSS 22.0 (versión) y todos los análisis se realizaron con este programa de estadísticas. Se proporcionó información descriptiva, subtítulos y puntajes totales de las escalas determinando los valores de frecuencia (f) y porcentaje (\%). El análisis de correlación se utilizó como procedimiento estadístico. Como resultado, si bien no hubo correlación entre educación física y docentes de desempeño laboral deportivo y justicia procesal, uno de los subtítulos de percepción de justicia, se encontró un bajo nivel de correlación negativa entre interacción, justicia distributiva y actitud hacia la justicia organizacional total. puntaje. Nuevamente, no se encontró relación entre el desempeño laboral y el puntaje total de oposición vertical y horizontal y oposición organizacional que son subtítulos de oposición organizacional. Esto puede deberse al hecho de que los administradores no recompensan adecuadamente el desempeño laboral de los maestros de educación física y deportes debido al creciente interés de los administradores hacia los maestros que imparten lecciones para exámenes importantes para los estudiantes. Además, se cree que se debe a que los profesores de educación física y deportes no tienen dificultades para expresarse debido tanto a sus competencias profesionales como a la autoexpresión y alta comunicación que les aportan la educación física y el deporte. 
Palabras clave: Educación física y deporte, docente, desempeño laboral, justicia organizacional, percepción, oposición organizacional.

\section{Introduction}

Nowadays which is defined as the information age with the innovations in information technologies, there is an increasing change at the global, social and organizational levels.

The changes and developments have changed the social values, professional competencies and knowledge and skills that people should have by affecting the education systems as well as different fields. Necessary information should be conveyed through an efficient education system for societies to survive and sustain their entities (Karaoğlu, \& Pepe, 2020). The teacher who has an crucial place in the national education system should be a good observer and guide in the teach and learn processes in order to ensure sufficiency in education.

In this direction, the job performance of teachers is very important in order to ensure sufficiency in education. It is possible to mention many definitions regarding job performance. According to Griffin, et al. (2007); Job performance is evaluated with the adequacy of the roles and job responsibilities of the individuals in the job description. According to another definition, job performance is the measurable business results, actions and behaviors of employees that contribute to the achievement of organizations' goals (Viswesvaran, \& Ones, 2000). To make a comprehensive definition, job performance is a concept related to what extent individuals working in organizations fulfill their duties and responsibilities in job descriptions, to what extent the organization achieves its goals, and

to what extent the individual's own outcomes are adequate. Organizational justice, which provides an increase in sense of belonging and job performance and a decrease in conflict, provides trust and loyalty for both organizations and employees (Cropanzano et al. 2007).

While justice is interpreted as behaviors appropriate to the things that come out of the human mind (Gözler, 2008), injustice is behaviors that reduce the labor and motivation of employees and have a destructive effect on the process. In summary; injustice is an important obstacle for the employee and the organization (Chegini, 2009). While Greenberg (1990) defines organizational justice as the organizational explanation of justice, according to Y1lmaz (2004), organizational justice includes the justice regarding all the social-economic changes within the organization and the mutual relations of the employees with the organization with all its stakeholders. Organizational justice is a concept related to the perception of the employee regarding whether he/she is treated fairly in the workplace (Moorman, 1991). The perception of business justice is a subjective perception that emerges as a result of a personal evaluation of the ethical and moral status of management (Colquitt et al. 2001; Cropanzano et al. 2007). In other words, they are the rules and social norms developed regarding the transactions and interpersonal practices used in the distribution of gains and distribution decisions (Folger, \& Cronpanzano, 1998).

Organizational justice perception forms the basis of many behaviors that employees exhibit in an organizationally. One of them is the opposition behavior of the employees. The communication between the employees within the organization causes the formation of a democratic environment by ensuring the flow of information within the organization, and accordingly, individuals have the opportunity to express different opinions and expectations. The development and continuity of organizations can only be possible with different ideas and thoughts which carries organizational opposition to a vital point for organizations (Kavak, \& Kaygın, 2018).

Organizational opposition basically can be evaluated as a concept that finds a field of existence for itself by expressing a disagreement. Although organizational opposition has a negative background as an expression of conflicts or different opinions, the act of opposition is an important organizational communication behavior. In this context, organizational opposition acts as a feedback mechanism where the managers can obtain information about what is happening in the organization or get feedback on the results of the planned decisions (Yildirım, 2020). Opposition is a qualified feedback and a form of reporting. Therefore, in this statement, the communication skills of the employees and the meaning they attach to the concept of opposition affect the organizational culture (Burns, \& Wagner, 2013). 
Organizational Justice Perception of Work Performance and Relationship of Work Performance with the Organizational Opposition Level: A Study on Physical Education and Sports Teachers (Istanbul Province Example

According to the literature review made by the researcher, although there are independent studies examining the following subjects ; job performance (Erkuş, \& Findıklı, 2013; Özutku, 2008; Gürbüz, \& Yüksel, 2008; Çelik, \& Çıra, 2013; Turunç, \& Çelik, 2010) organizational justice perception (Titrek, 2009; Y1lmaz, 2010; Cihangiroğlu, \& Y1lmaz 2010; Karacaoğlu, \& Yörük, 2012; Özgan, \& Bozbayındır, 2011) and organizational opposition (Kassing, \& Dicioccio, 2004; Packer, 2010; Özdemir, 2010) there is no study examining the relationship between job performance, organizational justice and organizational opposition on educational institutions at the same time. This situation presents the importance of this study offered.

The aim of this study is to examine the relationship between the job performance of physical education and sports teachers and their level of organizational justice and opposition.

\section{Methodology}

\section{Research Model}

In line with the research purpose, the study method is in the quantitative research relational survey model.

\section{Forming Volunteer Groups}

The research will be conducted with the study sample group. The sample group was composed of 575 physical education and teachers of sports who were selected by the simple random method (Çıng1, 1994) among individuals who worked as physical education and sports teachers in the state schools affiliated to the Istanbul Provincial Directorate of National Education in the 20192020 academic years.

\section{Data Collection Tools}

The scales applied in the research were implemented by the researcher to each of the candidates by visiting the educational institutions where the teachers worked a healthy evaluation process has been established for candidates within a wide period of time, without haste, by making the necessary explanations.

Personal information form, job performance, organizational justice and organizational opposition scales were implemented to participants.

\section{Personal Information Form}

While creating the personal information form of the study, the studies on job performance, organizational justice and organizational opposition were examined in the literature and series consisting of the characteristics wanted to be examined about teachers has been created. This form contains 6 questions including gender, age, seniority year, education level they serve, education and marital status of the participants. Personal information obtained from the participants is presented in Table 1 .

Table 1. Socio demographic characteristics of the participants

\begin{tabular}{|c|c|c|c|}
\hline & Variable & $\mathbf{N}$ & $\%$ \\
\hline \multirow[t]{8}{*}{ Age } & $22-26$ & 72 & 12,5 \\
\hline & $27-31$ & 115 & 20,0 \\
\hline & $32-36$ & 67 & 11,7 \\
\hline & $37-41$ & 95 & 16,5 \\
\hline & $42-46$ & 83 & 14,4 \\
\hline & $47-51$ & 61 & 10,6 \\
\hline & $52-56$ & 30 & 5,2 \\
\hline & $57-61$ & 52 & 9,0 \\
\hline \multirow[t]{2}{*}{ Gender } & Woman & 220 & 38,3 \\
\hline & Man & 355 & 61,7 \\
\hline \multirow[t]{5}{*}{ Seniority Year } & $1-5$ & 183 & 31,8 \\
\hline & $6-10$ & 117 & 20,3 \\
\hline & $11-15$ & 89 & 15,5 \\
\hline & $16-20$ & 90 & 15,7 \\
\hline & $21-26$ & 46 & 8,0 \\
\hline
\end{tabular}




\begin{tabular}{|c|c|c|c|}
\hline & $27-31$ & 22 & 3,8 \\
\cline { 2 - 4 } & 31 and over & 28 & 4,9 \\
\hline \multirow{3}{*}{ Education Status } & Undergraduate & 209 & 36,3 \\
\cline { 2 - 4 } & Master's Degree & 320 & 55,7 \\
\cline { 2 - 4 } & Doctorate & 46 & 8,0 \\
\hline \multirow{2}{*}{$\begin{array}{c}\text { Education Level } \\
\text { They Serve }\end{array}$} & $\begin{array}{c}\text { Elementary } \\
\text { education }\end{array}$ & 124 & 21,6 \\
\cline { 2 - 4 } & Secondary education & 451 & 78,4 \\
\hline Marital Status & Married & 253 & 44,0 \\
\cline { 2 - 4 } & Single & 257 & 44,7 \\
\cline { 2 - 4 } & Divorced & 65 & 11,3 \\
\hline
\end{tabular}

Note. $N=$ number of participant, $\%=$ percentage

In Table 1, it is determined that according to the age groups of the participants, $12.5 \%$ of the participants are 22-26, 20.0\% 27-11, 11.7\% 32-36, 16.5\% 37-41, 14.4\% 42-46, 10.6\% 47-51 years, 5.2\% 52-56 and 9.0\% 57-61 years, according to gender groups, $38.3 \%$ are women, $61.7 \%$ are men, according to seniority years, $31.8 \%$ is $1-5,20.3 \%$ is $6-10,15.5 \%$ is $11-15,15.7 \%$ is 16 $20,8.0 \%$ is $21-26,3,8 \% 27-31$ and $4,9 \% 31$ years and above, according to their educational status, $36.3 \%$ is undergraduate, $55.7 \%$ is a master's degree and $8.0 \%$ is a doctorate, according to the education level they serve, $21.6 \%$ of them are primary education, $78.4 \%$ are secondary education, and according to their marital status, $44.0 \%$ were married, $44.7 \%$ were single and $11.3 \%$ were divorced.

Job Performance Scale

The job performance scale of Kirkman \& Rosen (1999) and Sigler \& Pearson (2000) were used to measure the job performance of Physical Education and sports teachers.

In both studies, the reliability coefficient is over .70. Reliability coefficient of the scale applied on academicians by Çöl in Turkey was determined as 82. The scale is in 4-item and 5-point Likert type and it was evaluated as $1=$ Strongly disagree... 5 = Strongly agree.

\section{Organizational Justice Perception Scale}

In the study, the organizational justice scale prepared by Moorman (1991) and adapted into Turkish by Yildırım (2010) was used. The scale consists of 25 questions and 3 subtitles. The first 7 questions in the questionnaire are about procedural justice, the next 10 questions are about interactional justice, and the last 8 questions are about distributive justice. Cronbach Alpha reliability analyzes of each of the organizational justice dimensions were conducted and their reliability was reported to be between 0.94 and 0.98 .

Therefore, the reliability of all variables has values well above the acceptable Cronbach Alpha level of 0.70 . The scale is in 5-point Likert type, and it is evaluated as $1=$ Strongly disagree... 5 = Strongly agree (Yıldırım, 2010).

\section{Organizational Opposition Scale}

The organizational opposition scale developed by Kassing (1998) was translated into Turkish by Dağlı (2005) and its validity and reliability analysis was performed.

In the analysis made during the adaptation of the scale to Turkish, the organizational opposition scale clearly stated or vertical opposition (articulated / upward dissent) is 9 items and $\mathrm{a}=.83$, horizontal opposition (lateral / latent dissent) is 9 items and $\mathrm{a}=.87$. When the item and factor structures of the scale are examined, it is seen that it is above normal values. Out of 18 items in the scale, items $1,4,5,9,10,12,14,15$ and 17 are within the scope of vertical opposition; items $2,3,6,7,8,11,13,16$ and 18 are within the scope of horizontal opposition. Items 1, 4, 5, 9 and 15 under the vertical opposition factor and items 13 and 16 under the horizontal factor were designed as reverse items. The scale is in 5-point Likert type and it is evaluated as 1-I do not agree at all; 5-I completely agree.

\section{Data analysis}

The data of the research were analyzed using IBM SPSS 22.00 package program. The normal distributions of the scale scores were evaluated by examining the skewness-kurtosis coefficient. The coefficients obtained as a result of the analysis were found in the \pm 2 range. 
Organizational Justice Perception of Work Performance and Relationship of Work Performance with the Organizational Opposition Level: A Study on Physical Education and Sports Teachers (Istanbul Province Example

Based on this information, it is accepted that the distribution is in the normal range for all dimensions.

Descriptive information, subtitles and total scores of the scales were given by determining the frequency (f) and percentage (\%) values. Correlation analysis was used as a statistical procedure.

Table 2. Skewness-Kurtosis and Kolmogrov Smirnov test significance level results of participants' scale scores

\begin{tabular}{|c|c|c|c|c|}
\hline Scales & N & Skewness & Kurtosis & $\begin{array}{c}\text { Kolmogrov } \\
\text { Smirnov }\end{array}$ \\
\hline Job Performance & 575 &, 592 & $-1,057$ &, 000 \\
\hline Procedure Justice & 575 &, 073 &, 059 &, 000 \\
\hline Interaction Justice & 575 &,- 539 &,- 330 &, 000 \\
\hline Distribution Justice & 575 &,- 708 &, 137 &, 000 \\
\hline $\begin{array}{c}\text { Organizational Justice } \\
\text { Total }\end{array}$ & 575 &,- 586 &,- 291 &, 000 \\
\hline Vertical Opposition & 575 &,- 790 &, 025 &, 000 \\
\hline Horizontal Opposition & 575 &,- 616 &, 155 &, 000 \\
\hline $\begin{array}{c}\text { Organizational Opposition } \\
\text { Total }\end{array}$ & 575 &,- 897 &, 366 &, 000 \\
\hline
\end{tabular}

\section{Results}

Table 3. Descriptive statistics of the scores that physical education and sports teachers got from the scales

\begin{tabular}{|c|c|c|c|c|}
\hline Scales & $\mathbf{N}$ & Min & Max & $\mathbf{x} \pm$ SS \\
\hline Job Performance & 575 & 18,00 & 20,00 & $18,419 \pm, 518$ \\
\hline Procedure Justice & 575 & 9,00 & 24,00 & $16,367 \pm 2,418$ \\
\hline Interaction Justice & 575 & 13,00 & 50,00 & $36,266 \pm 9,027$ \\
\hline Distribution Justice & 575 & 8,00 & 40,00 & $29,226 \pm 7,517$ \\
\hline $\begin{array}{c}\text { Organizational Justice } \\
\text { Total }\end{array}$ & 575 & 34,00 & 111,00 & $81,859 \pm 16,779$ \\
\hline Vertical Opposition & 575 & 17,00 & 39,00 & $29,630 \pm 4,868$ \\
\hline Horizontal Opposition & 575 & 19,00 & 35,00 & $28,690 \pm 3,135$ \\
\hline $\begin{array}{c}\text { Organizational } \\
\text { Opposition Total }\end{array}$ & 575 & 38,00 & 73,00 & $58,320 \pm 7,447$ \\
\hline
\end{tabular}

When Table 3 is examined, it was determined that the average job performance scale of the

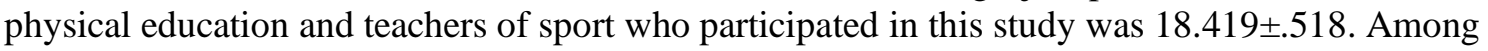
the subheadings of organizational justice perception; it was determined that the average of procedural justice was $16.367 \pm 2.418$, the average of interaction justice was $36.266 \pm 9.027$, the average of distributive justice was $29.226 \pm 7.517$, and the average of organizational justice perception was $81.859 \pm 16.779$. Among the subtitles of organizational opposition perception, it was determined that the vertical opposition average was $29,630 \pm 4,868$, the horizontal opposition average was $28,690 \pm 3,135$ and the total average of organizational opposition was 58,320 $\pm 7,447$.

Table 4. The connection between physical education and sports teachers' job performance and organizational justice perceptions $(n=575)$

\begin{tabular}{|c|c|c|c|c|c|c|}
\hline & & $\mathbf{1}$ & $\mathbf{2}$ & $\mathbf{3}$ & $\mathbf{4}$ & $\mathbf{5}$ \\
\hline \multirow{2}{*}{ Job Performance $^{\mathbf{1}}$} & $\mathrm{r}$ & 1 & & & & \\
\hline & $\mathrm{p}$ & & & & & \\
\hline \multirow{2}{*}{ Procedure Justice $^{2}$} & $\mathrm{r}$ &,- 042 & 1 & & & \\
\hline & $\mathrm{p}$ &, 311 & & & & \\
\hline \multirow{2}{*}{ Interaction Justice $^{\mathbf{3}}$} & $\mathrm{r}$ &,- 243 &, 318 & 1 & & \\
\hline & $\mathrm{p}$ &, 000 &, 000 & & & \\
\hline
\end{tabular}




\begin{tabular}{|c|c|c|c|c|c|c|}
\hline Distribution Justice $^{4}$ & $\mathrm{r}$ &,- 271 &, 225 &, 852 & 1 & \\
\cline { 2 - 7 } & $\mathrm{p}$ &, 000 &, 000 &, 000 & & \\
\hline Organizational Justice Total $^{\mathbf{5}}$ & $\mathrm{r}$ &,- 258 &, 416 &, 966 &, 939 & 1 \\
\cline { 2 - 7 } & $\mathrm{p}$ &, 000 &, 000 &, 000 &, 000 & \\
\hline
\end{tabular}

$* * \mathrm{p}<0.001 ; \mathrm{p}=$ significance level; $\mathrm{r}=$ correlation coefficient

When Table 4 is examined, there was no relationship between the job performance of participants and procedural justice that is one of the subtitles of perception of justice $(r=-, 042 ; p=, 311)$ while a low level of negative correlation was found between interaction justice $(r=-.243 ; \mathrm{p}=$ $.000)$, distribution justice $(\mathrm{r}=-.271 ; \mathrm{p}=.000)$ and total score of behavior towards organizational justice $(\mathrm{r}=-, 258 ; \mathrm{p}=, 000)$.

Table 5. The connection between physical education and job performance of sports teachers and organizational opposition perceptions $(n=575)$

\begin{tabular}{|c|c|c|c|c|c|}
\hline & & 1 & 2 & 3 & 4 \\
\hline \multirow[t]{2}{*}{ Job Performance $^{1}$} & $\mathrm{r}$ & 1 & & & \\
\hline & $\mathrm{p}$ & & & & \\
\hline \multirow[t]{2}{*}{ Vertical Opposition $^{2}$} & $\mathrm{r}$ &,- 056 & 1 & & \\
\hline & $\mathrm{p}$ & , 179 & & & \\
\hline \multirow[t]{2}{*}{ Horizontal Opposition $^{3}$} & $\mathrm{r}$ & ,060 & ,718 & 1 & \\
\hline & $\mathrm{p}$ & ,153 & ,000 & & \\
\hline \multirow{2}{*}{$\begin{array}{c}\text { Organizational Opposition } \\
\text { Total }^{4}\end{array}$} & $\mathrm{r}$ & ,062 & ,956 & 891 & 1 \\
\hline & $\mathrm{p}$ & ,139 & 000 & ,000 & \\
\hline
\end{tabular}

When Table 5 is examined, no relationship has been identified between job performance of physical education and sports teachers and organizational opposition subtitles regarding vertical opposition, horizontal opposition $(\mathrm{r}=.060 ; \mathrm{p}=.153)$ and organizational opposition total score $(\mathrm{r}=, 062 ; \mathrm{p}=, 139)$.

\section{Discussion}

In order for the human resources to work effectively and efficiently, it is extremely important to adopt the organizational goals and to increase the work performance and organizational commitment of the people in this direction (Akınc1, \& Karaoğlu, 2020).

Organizations need and value well-performing employees to achieve their goals, provide excellent service, and gain competitive advantage. Performance is also important for employees as it is a source of pride, pleasure and satisfaction. Moreover, it is important for employees, as high performance allows for better career opportunities and it is often rewarded with financial and / or other advantages such as easy promotion (Rageb et al. 2013). Therefore, employees with high job performance are expected to have high perceptions of organizational justice.

In the literature study conducted by the researcher, Doğan (2018) reported that there is a positive significant connection between the job performance of the tourism sector employees and their perceptions of organizational justice. Çakmak (2005) tested the relationship between performance evaluation systems and organizational justice perception. As a result of the research, the relationship between the justice perceptions of the employees regarding the performance evaluation system was determined. Robinson (2004) investigated the relationship between organizational justice and job performance and concluded that organizational justice is an important determinant of job performance. In another study, it was stated that was a significant positive relationship between teachers' performances and their perceptions of organizational justice (Kahraman, \& Çankaya, 2015).

In this study presented in response to this information in the literature, while there was no relationship between the job performance of participants and justice of procedure which is one of 
Organizational Justice Perception of Work Performance and Relationship of Work Performance with the Organizational Opposition Level: A Study on Physical Education and Sports Teachers (Istanbul Province Example

the subtitles of perception of justice, a low level of negative correlation was found between interaction justice and distribution justice and total score of attitude towards organizational justice.

Job performance is defined as the employee's doing or completing the job expected of him/her. However, not only the knowledge and skills of the personnel but also many factors within and outside the organization are effective in business success (Eren, \& Hayatoğlu, 2011; Y1ldız et al. 2014). The organizational justice approach emerges as one of these factors. Organizational justice can be defined as employee task distribution, overtime compliance, authorization, wage level, reward distribution, the way how developing managerial decisions regarding the conditions of a socially and economically fair working environment are taken and evaluated or the way employees perceive how these decisions are told to them (Kaneshiro, 2008).

It is the perception of justice regarding the attitudes and behaviors that employees are exposed to during the execution of organizational decisions and Informing the employees adequately about organizational decisions while administrators implement the processes related to organizational activities (distributional and procedural) (Liao, \& Tai, 2006; Cohen-Charash, \& Spector, 2001). If managers or executive representatives interact with employees on a fair basis, employees will respond with a higher job performance (Masterson et al. 2000; Cropanzano et al. 2007).

Bias of managers in employee promotion or job distribution, inequalities in performance evaluation, lack of open and honest communication, inadequate rewarding of employees causes damage to the perception of organizational justice among employees (İyigün, 2012). Shaking teachers' perceptions of organizational justice causes the feeling of trust towards managers to be damaged and the sense of belonging and commitment to be negatively affected (Baş, \& Şentürk, 2011). In this presented study, it is thought that the reason of the negative relationship between job performance and perception of justice sourced from increasing interest towards teachers conducting lessons for exams important in terms of students, in making, communicating and implementing decisions by managers in educational organizations. It is thought to be caused by the fact that they are not rewarded sufficiently by the managers, in return for the job performance of participants. No relationship has been identified between job performance of physical education and teachers of sports and vertical and horizontal opposition which are subtitles of organizational opposition and organizational opposition total score. In the literature review conducted by the researcher, there is no study examining the relationship between job performance and organizational opposition. However, it has been found that it is associated with various variables such as organizational opposition and climate perception (Karalar, \& Usta-Kara, 2020), personal values and psychological well-being (Acaray, 2018), five-factor personality model (Ökten, \& Cenkçi, 2013), organizational power games (Korucuoğlu, \& Şentürk, 2018) organizational cynicism and organizational commitment (Y1ldı 2013) critical thinking dispositions (Püsküllüoğlu, \& Altınkurt, 2018) and perception of professional self-efficacy (Bakan, et al. 2017).

The concept of organizational opposition has a very important place in the formation and development of democracy within the organization. In addition, organizational opposition also contributes greatly to the solution of the problems that arise within the organization and at the point of preventing possible problems before they occur (Kassing, \& Armstrong, 2002). It is an issue that especially needs to be dwelled on sensitively by managers in terms of the democratization of organizations (Ötken, \& Cenkçi, 2013). Organizational opposition as well as playing an important role in the democratization of the organization is important for organizational communication, interaction and performance when it is thought that it can contribute to the development of the organization, identifying the problems within the organization, taking necessary measures to solve these problems (Kassing, 2001).

In this presented study, it is thought that the reason of not finding any relationship between job performance and organizational opposition perceptions originated from both professional competencies of physical education and sports teachers and self-expression ability that physical education and sports give them and not having any trouble expressing themselves due to their high communication skills. 


\section{Conclusion}

As a result, while a low level of negative correlation was detected between job performance of physical education and sports teachers and the perception of justice subtitles, interaction and distribution justice and attitude total score towards organizational justice, no relationship was determined between the organizational opposition subtitles, vertical and horizontal opposition, and the organizational opposition total score. This may be due to the fact that administrators do not adequately reward the job performances of physical education and sports teachers due to increasing interest of managers towards teachers who conduct lessons for exams important in terms of students. In addition, it is thought to be caused that physical education and sports teachers do not have any difficulties in expressing themselves due to both their professional competencies and their self-expression and high communication skills that physical education and sports bring them.

\section{References}

Acaray, A. (2018). Örgütsel Muhalefetin Kişisel Değerler ve Psikolojik İyi Oluş İle İlişkinin İncelenmesi. Business \& Management Studies: An International Journal, 6(3), 171-189.

Akıncı, A.Y., Karaoğlu, B. (2020). Beden Eğitimi Öğretmenlerinin İş Performansı İle Örgütsel Adalet Algıları Arasındaki İlişkinin İncelenmesi. Sosyal Bilimler Dergisi, 7(46),155-165.

Bakan, İ., Doğan, İ.F., Yılmaz, Y.S. (2017). Çalışanlarda Mesleki Öz Yeterlilik Algısı İle Örgütsel Muhalefet İlişkisi. Organizasyon Ve Yönetim Bilimleri Dergisi, 9(2), 54-70.

Burns, T., Wagner, C. (2013). Organizational Dissent. Principal Leadership, 14 (4),28-32.

Chegini, M.G. (2009). The Relationship Between Organizational Justice and Organizational Citizenship Behavior. American Journal of Economics and Business Administration, 1(2), 173-176.

Cihangiroğlu, N., Yılmaz, A. (2010). Çalışanların Örgütsel Adalet Algısının Örgütler İçin Önemi. S.Ü. I.I. B.F Sosyal ve Ekonomik Araştırmalar Dergisi, 10(19), 195-213.

Cohen-Charash, Y., Spector, P.E. (2001). The Role of Justice in Organizations: A Metaanalysis. Organizational Behavior and Human Decision Processes, 86, 278-321.

Colquitt J.A., Conlon D.E., Wesson M.J., Porter COLH \& NG KY, (2001). Justice At The Millennium. A Meta-Analytic Review Of 25 Years Of Organizational Justice Research. Journal of Applied Psychology, (86),425-445.

Cropanzano, R., Bowen, D.E., Gilliland ,S.W. (2007). The Management Of Organizational Justice. Academy of Management Perspectives, 21(4), 34- 48.

Çakmak, Ö.K. (2005). Performans Değerlendirme Sistemlerinde Örgütsel Adalet Algısı ve Bir Örnek Olay Çalışması, Yayınlanmamış Doktora Tezi, İstanbul Üniversitesi, Sosyal Bilimler Enstitüsü, İstanbul.

Çelik, M., Çıra, A. (2013). Örgütsel Vatandaşlık Davranışının İş Performansı ve İşten Ayrılma Niyeti Üzerine Etkisinde Aşırı İş Yükünün Aracılık Rolü. Ege Akademik Bakış, 13(1), 1120.

Çıngı, H. (1994). Örnekleme kuramı, Hacettepe Üniversitesi Basımevi, Ankara.

Çöl, G. (2008). Algılanan güçlendirmenin işgören performansı üzerine etkileri. Doğuş Üniversitesi Dergisi, 9(1), 35-46.

Dağlı, A. (2005). Örgütsel Muhalefet Ölçeği Türkçe’ye Uyarlanması: Geçerlilik ve Güvenirlik Çalışması. Elektronik Sosyal Bilimler Dergisi, 14 (53),198-218.

Doğan, H. (2018). Örgütsel Adalet Algısı İle İş Performansı Arasındaki İlişki. Kastamonu Üniversitesi İktisadi ve İdari Bilimler Fakültesi Dergisi, 20(2), 26-46.

Eren, S.S., Hayatoğlu, Ö. (2011). Etik İkliminin Satış Elemanlarının İş Tutumlarına ve İş Performanslarına Etkisi İlaç Sektöründe Bir Uygulama. ZKÜ Sosyal Bilimler Dergisi, 7 (14), 109-128.

Erkuş, A., Fındıklı, M.A. (2013). Psikolojik Sermayenin İş Tatmini, İş Performansı ve İşten Ayrılma Niyeti Üzerindeki Etkisine Yönelik Bir Araştırma. İstanbul Üniversitesi Iş̧letme Fakültesi Dergisi, 42(2), 302-318. 
Organizational Justice Perception of Work Performance and Relationship of Work Performance with the Organizational Opposition Level: A Study on Physical Education and Sports Teachers (Istanbul Province Example

Folger, R., Cropanzano, R. (1998). Organizational Justice and Human Resource Management, Sage, London.

Gözler, K. (2008). Tabii Hukuk ve Hukuki Pozitivizme Göre Adalet Kavramı.. Muhafazakâr Düşünce, 4(15):77-90.

Greenberg, J. (1990). Looking Fair vs. Being Fair: Managing Impressions of Organizational Justice. In BM Staw \& LL Cummings (Eds.), Research in organizational behavior, 12, 11157. Greenwich, CT: JAI Press.

Griffin, M.A, Neal, A ., Parker, S.K. (2007). A New Model Of Work Role Performance: Positive Behavior in Uncertain and Interdependent Contexts. Academy of Management Journal, 50(2), 327-347.

Gürbüz, S., Yüksel, M. (2008). Çalışma Ortamında Duygusal Zekâ: İş Performansı, İş Tatmini, Örgütsel Vatandaşlık Davranışı ve Bazı Demografik Özelliklerle İlişkisi. Doğuş Üniversitesi Dergisi, 9 (2), 174-190.

İyigün, Ö.N. (2012). Örgütsel Adalet. Kuramsal Bir Yaklaşım. İstanbul Ticaret Üniversitesi Sosyal Bilimler Dergisi, 11(21), 51-60.

Kahraman, Ü., Çankaya, İ.H. (2015). İlkokullarda Performans Yönetimi Uygulamaları ve Öğretmenlerin Örgütsel Adalet Algıları Arasındaki İlişki. Turkish Studies (Elektronik), 10(7), 519-540.

Kaneshiro, P. (2008) Analyzing the Organizational Justice, Trust and Commitment Relationship in a Public Organization, Arizona,Northcentral University.

Karacaoğlu, K., Yörük, D. (2012). Çalışanların Nepotizm ve Örgütsel Adalet Algılamaları. Orta Anadolu Bölgesinde Bir Aile İşletmesi Uygulaması.. İş, Güç, Endüstri İlişkileri ve İnsan Kaynaklarl Dergisi, 14(3), 43-64.

Karalar, S., Usta-Kara, I., (2020). Katılımcı İklim Alg1sı İle Örgütsel Muhalefet Arasındaki İlişkinin İncelenmesi. Afyon Kocatepe Üniversitesi Sosyal Bilimler Dergisi, 22(3), 714729.

Karaoğlu, B., Pepe, O. (2020). Beden Eğitimi Öğretmen Adaylarının Akademik Öz Düzenleme Becerilerinin Bazı Değişkenlere Göre İncelenmesi. Beden Eğitimi ve Spor Bilimleri Dergisi, 14(2), 214-224.

Karasar, N. (2004). Bilimsel Araştırma Yöntemi. Nobel yayıncılık, Ankara, 52.

Kassing, J.W. (1998). Development and Validation of the Organizational Dissent Scale. Management Communication Quarterly, 12(2),183-229.

Kassing, J.W. (2001). From the Look of Things: Assessing Perceptions of Organizational Dissenters, Communication Research, 21, 553-574.

Kassing, J.W., Dicioccio, R.L. (2004). Testing A Workplace Experience Explanation Of Displaced Dissent. Communication Reports, (17), 111-120.

Kassing, J.W., Armstrong T.A. (2002). Someone's Going to Hear About This: Examining the Association Between Dissent-Triggering Events and Employee's Dissent Expressions. Management Communication Quarterly, (16), 39-65.

Kavak, O., Kaygın, E. (2018). Örgütsel Adalet Algısının Örgütsel Muhalefet Davranışı Üzerindeki Etkisi. Balkan and Near Eastern Journal of Social Science, 4(1),33-51.

Kirkman, B.L., Rosen, B. (1999). Beyond Self-management. Antecedents and Consequences of Team Empowerment. Academy of Management Journal, 42(1), 58-74.

Korucuoğlu, T., Şentürk, İ. (2018). Örgütsel Güç Oyunları ve Örgütsel Muhalefet Arasındaki İlişki (İlkokul Ve Ortaokullarda Görev Yapan Öğretmen Görüşleri Bağlamında). Hacettepe Üniversitesi Eğitim Fakültesi Dergisi, 35(2), 428-447.

Liao, W.C., Tai, W.T. (2006). Organizational Justice, Motivation to Learn, and Training Outcomes. Social Behavior and Personality, 34(5),545-556.

Masterson, S.S., Lewis, K., Goldman, B.M., Taylor, M.S. (2000). Integrating Justice and Social Exchange: The Differing Effects of Fair Procedures and Treatment on Work Relationships. Academy of Management Journal, 43(4), 738-748.

Moorman, R.H. (1991). Relationship Between Organizational Justice and Organizational Citizenship Behaviors. Do Fairness Perceptions Influence Employee Citizenship? Journal of Applied Psychology, 76(6), 845-855. 
Ökten, A.B., Cenkçi, T. (2013). Beş Faktör Kişilik Modeli Ve Örgütsel Muhalefet Arasındaki İlişki Üzerine Bir Araştırma, Öneri, (39), 41-51.

Özdemir, M. (2010). Ankara İli Kamu Genel Liselerinde Görev Yapan Yönetici Ve Öğretmenlerin Örgütsel Muhalefete İlişkin Görüşleri, Doktora Tezi, Ankara Üniversitesi, Eğitim Bilimleri Enstitüsü, Ankara.

Özgan, H., Bozbayındır, F. (2011). Okullarda Adil Olmayan Uygulamalar ve Etkileri.. Dicle Üniversitesi Ziya Gökalp Ĕgitim Fakültesi Dergisi, (16), 66-85.

Özutku, H. (2008). Örgüte Duygusal, Devamlılık ve Normatif Bağl1lık ile İş Performansı Arasındaki İlişkinin İncelenmesi. İstanbul Üniversitesi İsletme Fakültesi Dergisi, 37(2), 79-97.

Packer, D.J. (2010). The Interactive Influence Of Conscientiousness and Openness to Experience on Dissent. Social Influence, (3), 202-219.

Püsküllüoğlu, E.I., Altınkurt, Y. (2018). Öğretmenlerin Eleştirel Düşünme Eğilimleri ile Örgütsel Muhalefet Davranışları Arasındaki İlişki. Hacettepe Üniversitesi Ĕ̈itim Fakültesi Dergisi, 33(4), 897-914.

Robinson, K. (2004). The Impact of Individual Differences on the Relationship between Employee Perceptions of Organizational Justice and Organizational outcome Variables, PhD Dissertation, Alliant International University, San Diego.

Sigler, T.H., Pearson, C.M. (2000). Creating an Empowering Culture: Examining The Relationship Between Organizational Culture and Perceptions of Empowerment. Journal of Quality Management, (5),7-52.

Titrek, O. (2009). Okul Türüne Göre Okullardaki Örgütsel Adalet Düzeyi. Uluslararası Insan Bilimleri Dergisi, 5(2), 551-573.

Turunç, Ö., Çelik, M. (2010). Çalışanların Algıladıkları Örgütsel Destek ve İş Stresinin Örgütsel Özdeşleşme ve İş Performansına Etkisi. Yönetim ve Ekonomi, 17(2), 183-206.

Viswesvaran, C., Ones, D.S. (2000). Perspectives on Models of Job Performance, International Journal of Selection and Assessment, (8), 216-226.

Yıldırım, A. (2010). Etik Liderlik ve Örgütsel Adalet İlişkisi Üzerine Bir Uygulama, Yayımlanmamış Yüksek Lisans Tezi, Karamanoğlu Mehmetbey Üniversitesi Sosyal Bilimler Enstitüsü, Karaman.

Yıldırım, A. (2020). Örgütsel Adalet Algısının Örgütsel Muhalefet Davranışına Etkisi: Eğitim Çalışanları Üzerine Bir Araştırma. Suleyman Demirel University Journal Of Faculty of Economics \& Administrative Sciences, 25(2), 203-219.

Yıldız, K. (2013). Örgütsel Bağlılık ile Örgütsel Sinizm ve Örgütsel Muhalefet Arasındaki İlişki. Electronic Turkish Studies, 8(6), 853-879.

Yıldız, S., Savcı, G., Kapu, H. (2014). Motive Edici Faktörlerin Çalışanların İş Performansına ve İşten Ayrılma Niyetine Etkisi, Yönetim ve Ekonomi, 21(1), 233-249.

Yılmaz, G. (2004). İnsan Kaynakları Uygulamalarına İlişkin Örgütsel Adalet Algısının Çalışanların Tutum ve Davranışları Üzerindeki Etkisi, Yayınlanmış Doktora Tezi, İstanbul Üniversitesi, Sosyal Bilimler Enstitüsü, İstanbul.

Yılmaz, K. (2010). Devlet Ortaöğretim Okullarında Görev Yapan Öğretmenlerin Örgütsel Adalet Algıları, Kuram ve Uygulamada Eğitim Bilimleri, 10(1), 579-616. 